\title{
ПРОБЛЕМИ НАДАННЯ ПАЛІАТИВНОЇ ДОПОМОГИ НЕВИЛІКОВНИМ ХВОРИМ У МІСТІ ОЛЕКСАНДРІЇ КІРОВОГРАДСЬКОЇ ОБЛАСТІ
}

\author{
А. С. Соловйова, Н. І. Рега, С. О. Ястремська \\ Тернопільський національний медичний університет \\ імені І. Я. Горбачевського МОЗ Украӥни
}

У статті висвітлено проблеми надання паліативної допомоги невиліковним хворим у м. Олександрії Кіровоградської області та запропоновано рекомендації щодо її покращення.

\section{PROBLEMS OF PALIATIVE CARE FOR INCURABLE PATIENTS IN OLEXANDRIIA, KIROVOHRAD REGION}

\author{
A. S. Solovyova, N. I. Rega, S. O. Yastremska
}

\section{Horbachevsky Ternopil National Medical University}

The article highlights the problems of providing palliative care to incurable patients in Olexandriia, Kirovohrad region and offers recommendations for its improvement.

Вступ. Сучасна медико-демографічна ситуація у світі та Україні характеризується прогресуючим постарінням населення. Це супроводжується й прогнозом зростання медико-соціального тягаря хронічних невиліковних недуг - злоякісних новоутворень, серцевої й дихальної недостатності, церебросудинних (цереброваскулярних) та нейродегенеративних захворювань, патології опорно-рухового апарату тощо [1]. Зростання потреби в паліативній допомозі, забезпечення гідного догляду за невиліковними пацієнтами наприкінці їхнього життя, спричинене загальним старінням населення та поширенням тяжких хронічних захворювань, є викликом для системи охорони здоров'я у багатьох країнах. Останнім часом про паліативну допомогу говорять досить часто й багато - що це, навіщо вона потрібна і хто зрештою ії потребує. Водночас практика комунікації з лікарями, досвід пацієнтів та їхніх близьких свідчать про глибоке нерозуміння суті паліативної допомоги представниками медичної системи [2].

Відповідно до Закону України від 19.10.2017 р. № 2168-VIII «Про державні фінансові гарантії медичного обслуговування населення», паліативна допомога (ПД) входить до медичних послуг, фінансування яких на первинному рівні здійснюється за державний кошт.
Згідно з пунктом 12 додатка 1 «Перелік медичних послуг з надання первинної медичної допомоги» наказу МОЗ України від 19.03.2018 р. № 504 «Про затвердження Порядку надання первинної медичної допомоги» передбачено надання окремих послуг паліативної допомоги пацієнтам усіх вікових категорій, що включає:

- регулярну оцінку стану тяжкохворого пацієнта та його потреб;

- оцінку ступеня болю та купірування больового синдрому;

- призначення наркотичних засобів та психотропних речовин відповідно до законодавства, включаючи оформлення рецептів для лікування при больовому синдромі;

- призначення лікування для подолання супутніх симптомів (закрепи, нудота, задуха тощо);

- консультування та навчання осіб, які здійснюють догляд за пацієнтом;

- координацію із забезпечення медичних, психологічних тощо потреб пацієнта [2-4].

Основна частина. Враховуючи вищевикладене, метою нашої роботи стало вивчення проблем надання ПД невиліковним хворим у м. Олександрії Кіровоградської області з метою розробки рекомендацій щодо її покращення. 
Базовою лікувально-профілактичною установою міста $є$ Комунальне підприємство «Центральна міська лікарня м. Олександрії» Олександрійської міської ради. Це багатопрофільна лікарня, яка надає цілодобово кваліфіковану та спеціалізовану лікарську допомогу, як планову, так і екстрену, жителям міста та навколишніх районів області.

У період нестійкої епідемічної ситуації в зв'язку зі захворюваністю на коронавірусну інфекцію COVID-19 лікувальний заклад працює в обмежувальному режимі.

На цей період:

- обмежено відвідування пацієнтів у стаціонарних відділеннях лікарні (відвідувачі обов'язково мають одягти маску медичну та пройти термометрію);

- призупинено планову госпіталізацію хворих та планові оперативні втручання;

- УЗД, лабораторні та функціональні обстеження мають проводити виключно за гострої клінічної необхідності;

- призупинено проведення планових медичних оглядів, фізіотерапевтичних процедур і ЛФК, роботу денних стаціонарів;

- буде організовано та забезпечено посилений протиепідемічний режим.

На сьогодні паліативну допомогу в м. Олександрії надають такі структури:

1. Основні обов'язки надання ПД у м. Олександрії покладено на міського онколога, який проводить прийом у міській поліклініці та забезпечує надання амбулаторної онкологічної допомоги мешканцям м. Олександрії та Олександрійського району.

2. Частково надання ПД здійснюють сімейні лікарі та медичні сестри загальної практики - сімейної медицини.

3. При появі ургентних станів ПД здійснюють у стаціонарних відділеннях Комунального підприємства «Центральна міська лікарня м. Олександрії» Олександрійської міської ради, найчастіше - у хірургічному відділенні.

3 метою оцінки якості надання ПД у м. Олександрії Кіровоградської області проведено анкетування 31 інкурабельного пацієнта (ІП). Серед опитаних було 16 (51,6 \%) чоловіків, 15 (48,4 \%) жінок (рис. 1).

Серед опитаних було 20 (64,5 \%) мешканців міста, 11 (35,5 \%) сільських мешканців (рис. 2).

Серед опитаних невиліковно хворих 12 (38,7\%) пацієнтів були працездатного віку, що свідчить про значну соціально-економічну проблему.

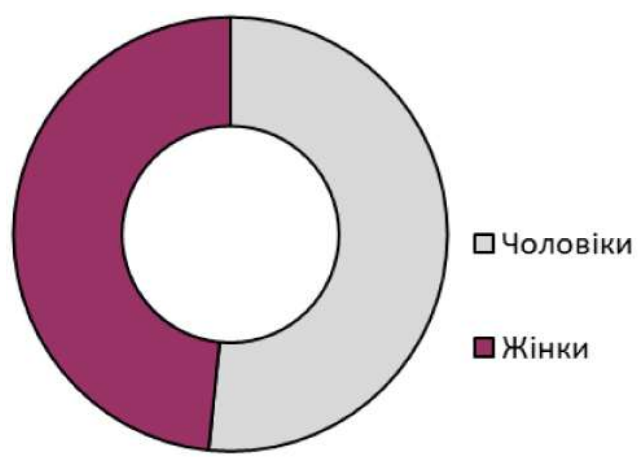

Рис. 1. Поділ респондентів за статтю.

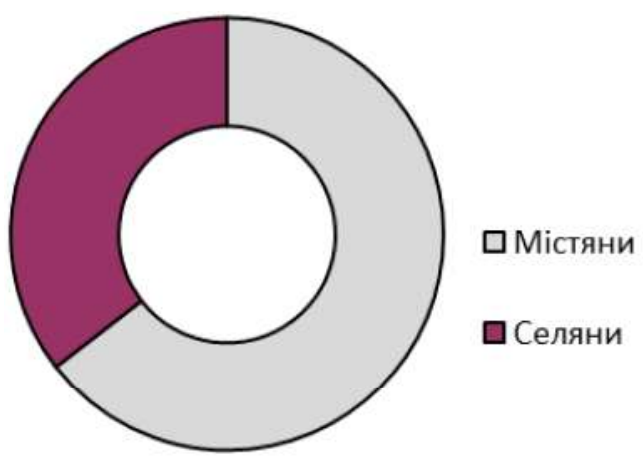

Рис. 2. Поділ респондентів за місцем проживання.

При суб'єктивній оцінці загального стану 17 (54,8 \%) респондентів оцінювали власне здоров'я як вкрай незадовільне, 8 (25,8 \%) - як незадовільне, 5 (16,1\%) як задовільне і тільки 1 (3,2 \%) - як добре (рис. 3).

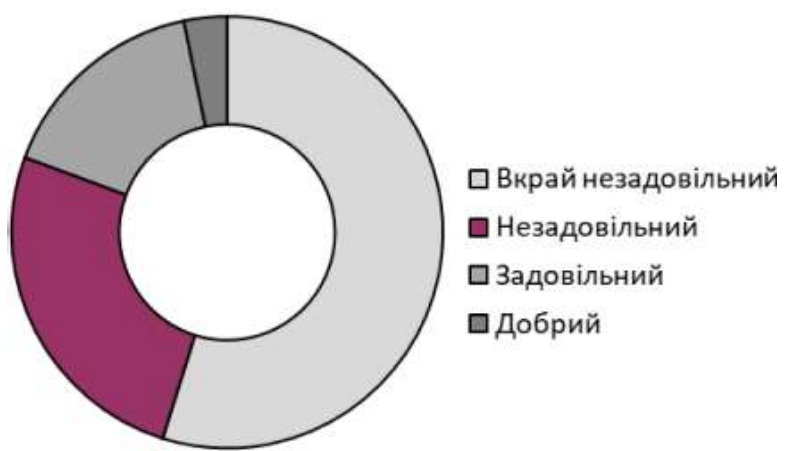

Рис. 3. Суб'єктивна оцінка інкурабельних пацієнтів загального стану здоров'я.

Більшість респондентів визнавала, що хвороба суттєво погіршила якість життя (96,7\%).

ІП часто потребували госпіталізації, пов'язаної $з$ розвитком ускладнень (кровотеча, кишкова непрохідність, виражений набряковий синдром, розвиток застійної пневмонії і под.).

Проаналізовано частоту госпіталізації ІП за останній рік та шляхи цієї госпіталізації. Виявлено, що протягом останнього року 22 (70,9 \%) пацієнти були госпіталізовані. При аналізі структури шляхів 
госпіталізації встановлено, що частка поступлень у стаціонар за направленням лікаря досить низька лише у 8 (36,3 \%) пацієнтів. 14 (63,7 \%) ІП доставлено в стаціонар ургентно, з них 12 - бригадою швидкої допомоги, а 2 - родичами в приймальне відділення лікарні з наполяганням на госпіталізації (рис. 4).

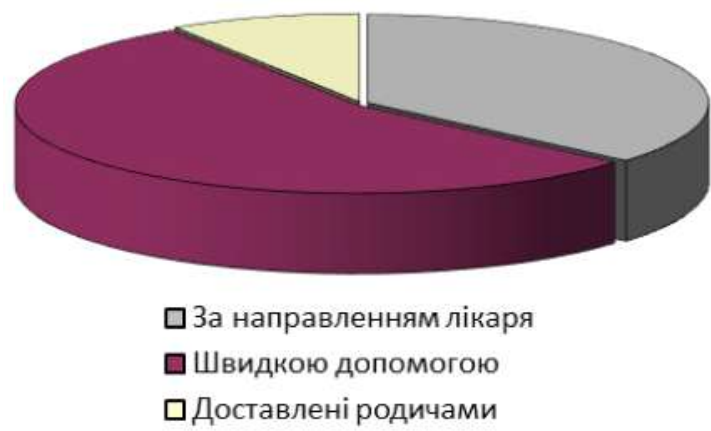

PUс. 4. Структура шляхів госпіталізації інкурабельних пацієнтів.

Аналіз шляхів госпіталізації показує, що більшість пацієнтів була госпіталізована ургентно у зв'язку із критичним погіршенням стану здоров'я, тобто госпіталізація була ургентною. Це вказує на те, що сімейні лікарі часто не виконують свою роль як організатора оптимального маршруту лікування ПД, а також на те, що має місце недостатньо налагоджена співпраця між сімейним лікарем та працівниками спеціалізованих стаціонарів. Участь родичів в ургентній госпіталізації пацієнта вказує на їх роль у прийнятті рішень щодо лікування пацієнта в обхід ланки первинної медикосанітарної допомоги.

Наявність тяжкого довготривалого хронічного захворювання вимагає великих матеріальних затрат на лікування і догляд ІП, які, за умов загального низького рівня доходів населення в Україні, лягають серйозним тягарем не тільки на державний та комунальний бюджети, а й переважно на плечі самих хворих та їх родин. Тому проведено опитування щодо матеріальної забезпеченості ІП та їх сімей. Результати наведено в таблиці 1 та на рисунку 5.

Таблиця 1. Самооцінка матеріальної забезпеченості інкурабельних пацієнтів та їх сімей

\begin{tabular}{|l|c|c|}
\hline \multicolumn{1}{|c|}{ Дохід } & Кількість сімей & $\%$ \\
\hline Високий & 1 & 3,2 \\
\hline Середній & 12 & 38,7 \\
\hline Недостатній & 18 & 58,1 \\
\hline
\end{tabular}

Практично всі респонденти вказували на поглиблення фінансових труднощів із часом.

Проведено опитування ІП щодо їх емоційного стану. Результати опитування наведено в таблиці 2.

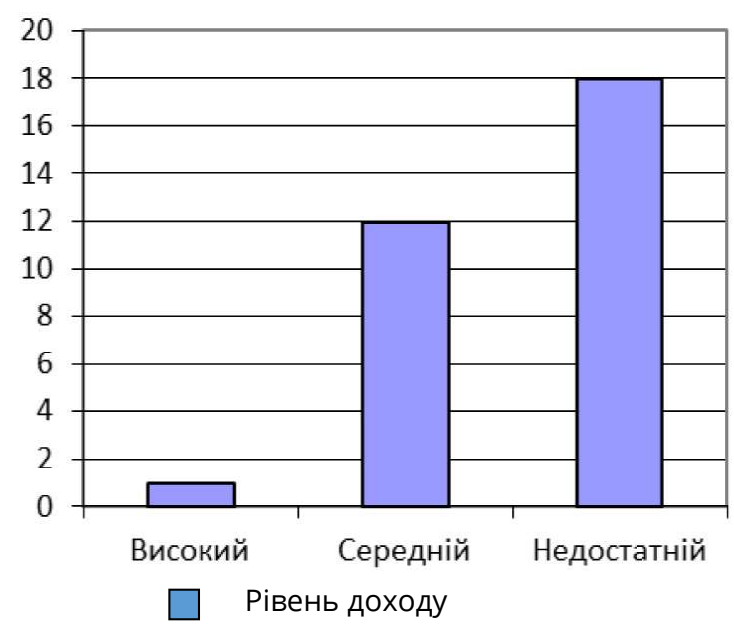

Рис. 5. Рівень матеріальної забезпеченості інкурабельних пацієнтів та їх сімей.

Таблиця 2. Емоційний стан інкурабельних пацієнтів

\begin{tabular}{|l|c|c|}
\hline \multicolumn{1}{|c|}{ Відчуття } & Кількість ІП & $\%$ \\
\hline $\begin{array}{l}\text { Непотрібності для сус- } \\
\text { пільства }\end{array}$ & 25 & 80,6 \\
\hline Розчарування в житті & 24 & 77,4 \\
\hline Самотності & 23 & 74,2 \\
\hline Байдужості до всього & 22 & 71,0 \\
\hline $\begin{array}{l}\text { Ізоляції від суспільного } \\
\text { життя }\end{array}$ & 24 & 77,4 \\
\hline Тягаря для родини & 21 & 67,7 \\
\hline
\end{tabular}

Як видно із даних таблиці, більшість ІП перебуває у пригніченому стані та почувається непотрібними як суспільству, так і членам своєї родини.

Вивчено думку пацієнтів про те, хто саме повинен забезпечувати догляд за ними. Результати опитування наведено в таблиці 3 та на рисунку 6.

\section{Таблиця 3. Забезпечення догляду за інкурабельними пацієнтами}

\begin{tabular}{|l|c|c|}
\hline \multicolumn{1}{|c|}{ Особи, які доглядають за ІП } & Кількість ІП & $\%$ \\
\hline Родичі & 7 & 22,6 \\
\hline Лікарі & 0 & 0 \\
\hline $\begin{array}{l}\text { Середній медичний персо- } \\
\text { нал }\end{array}$ & 11 & 35,5 \\
\hline $\begin{array}{l}\text { Молодший медичний пер- } \\
\text { сонал }\end{array}$ & 12 & 38,7 \\
\hline Соціальні працівники & 1 & 3,2 \\
\hline Волонтери & 0 & 0 \\
\hline
\end{tabular}

Вивчення думки пацієнтів показало, що, попри загальновідому суттєву участь родичів у догляді, досить низький відсоток ІП погоджувався з цим (табл. 3). Такі відповіді можуть бути як наслідком небажання пацієнтів бути тягарем для своїх рідних, так і недостатньою компетентністю близьких у питаннях догляду. Як видно із рисунка 6, основними надавачами 


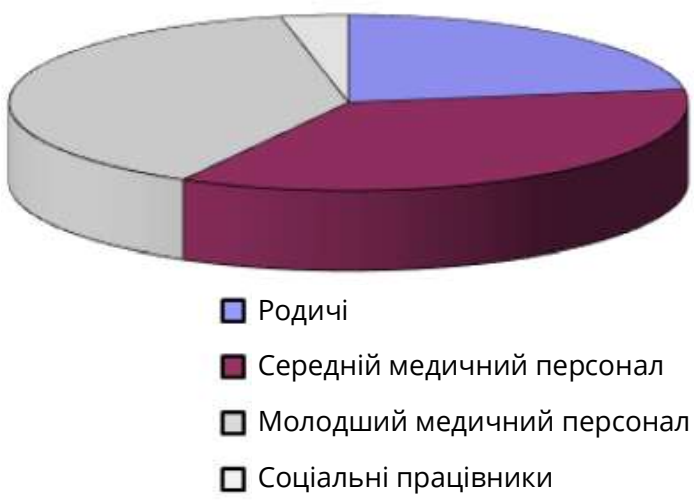

Puc. 6. Особи, які здійснюють догляд за інкурабельними пацієнтами.

послуг респонденти вважали молодший та середній медичний персонал.

При відповіді на запитання, чи повинні особи, які здійснюють догляд за хворими, проходити спеціальну підготовку, 29 (93,5 \%) респондентів були в цьому переконані.

Проведено опитування ІП щодо претензій до надання медичної допомоги. Результати опитування наведено в таблиці 4.

Таблиця 4. Проблеми, які викликають незадоволення інкурабельних пацієнтів у сучасній системі охорони здоров'я

\begin{tabular}{|l|c|c|}
\hline \multicolumn{1}{|c|}{ Проблема } & Кількість ІП & $\%$ \\
\hline Висока вартість медикаментів & 30 & 96,8 \\
\hline $\begin{array}{l}\text { Висока вартість медичних } \\
\text { послуг }\end{array}$ & 26 & 83,9 \\
\hline $\begin{array}{l}\text { Недостатнє фінансування ме- } \\
\text { дичних закладів }\end{array}$ & 27 & 87,1 \\
\hline $\begin{array}{l}\text { Недостатнє обладнання медич- } \\
\text { них закладів }\end{array}$ & 21 & 67,7 \\
\hline $\begin{array}{l}\text { Використання застарілих } \\
\text { технологій }\end{array}$ & 23 & 71,0 \\
\hline $\begin{array}{l}\text { Некомфортні умови перебу- } \\
\text { вання в закладі }\end{array}$ & 64,2 \\
\hline $\begin{array}{l}\text { Недостатній професіоналізм } \\
\text { персоналу }\end{array}$ & 7 & 22,6 \\
\hline $\begin{array}{l}\text { Неналежне ставлення персо- } \\
\text { налу до пацієнтів }\end{array}$ & 14 & 25,8 \\
\hline Нескоординованість допомоги & 85,2 \\
\hline $\begin{array}{l}\text { Територіальна віддаленість } \\
\text { необхідної допомоги }\end{array}$ & 7 & \\
\hline
\end{tabular}

Як видно із таблиці 4, основні претензії до системи охорони здоров'я лежать в суспільно-економічній площині. Найбільше інкурабельні хворі були невдоволені високою вартістю медикаментів (96,8 \%), коштовними медичними послугами $(83,9 \%)$, недостатнім фінансуванням медичних закладів (87,1%), застарілими технологіями (71,0 \%) та некомфортними умовами перебування в 303 (74,2 \%). Це цілком зрозуміло, враховуючи, що тривале невиліковне захворювання часто фінансово виснажує як самого хворого, так і його близьких, а більшість інкурабельних хворих вважає себе малозабезпеченими. Наступні претензії респондентів були сфокусовані на кадрових проблемах системи охорони здоров'я. Так, значна частина респондентів обурювалась неналежним ставленням до них медпрацівників (22,6\%), непрофесійними $(19,4$ \%), на їх думку, та нескоординованими (25,8 \%) діями медичного персоналу.

Одним із основних завдань паліативної допомоги забезпечення права кожного на гідну смерть. Тому ми провели опитування ІП щодо того, де б вони хотіли закінчити свій життєвий шлях. Результати опитування наведено на рисунку 7.

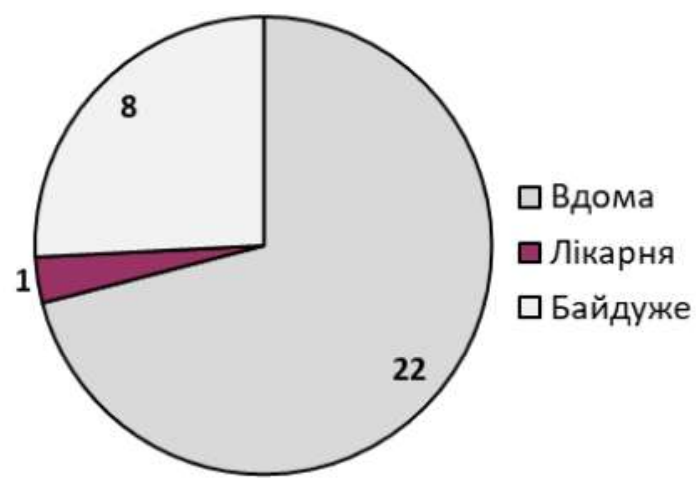

Рис. 7. Місце смерті інкурабельних пацієнтів.

У дослідженні встановлено, що більшість опитаних невиліковно хворих (71,0 \%) бажала б померти вдома. Мізерна частка опитаних (3,2%) місцем завершення свого життєвого шляху бачила лікарню. Разом із тим, 25,8 \% ІП місце смерті не турбувало.

Висновки. 3 вищевикладеного зрозуміло, що надання ПД у м. Олександрії потребує серйозних змін, зокрема:

- збільшення кадрового потенціалу;

- створення стаціонарного хоспісного відділення;

- створення мобільних бригад з надання Пд;

- організації волонтерського руху;

- організації співпраці структур, які надають ПД, із центрами ПМСД, волонтерами, громадами та духовенством. 


\section{СПИСОК ЛІТЕРАТУРИ}

1. Сучасні завдання по реформуванню галузі охорони здоров'я та розвитку вищої медичної освіти і науки / О. В. Аніщенко, О. К. Толстанов, В.В.Вороненко та ін. // Вища освіта в медсестринстві: проблеми і перспективи : матеріали Всеукр. наук.-практ. конф., приуроченої до 135-річниці заснування Житомирського інституту медсестринства (Житомир, 28-29 квітня 2010 р.) / за ред. В. Й. Шатила. - Житомир : Полісся, 2011. - С. 3-31.

2. Гузій О. Паліативна допомога в Україні: що має змінитися [Електронний ресурс] / О. Гузій // Український медичний часопис. - 2018. - С. 1-7. - Режим доступу : https://www.umj.com.ua/wp/wp-content/uploads/2018/09/ PaliativnaMOZ.pdf?upload $=$.

3. Про державні фінансові гарантії медичного обслуговування населення : Закон України від 19.10.2017 р. № 2168-VIII.

4. Про затвердження Порядку надання первинної медичної допомоги : наказ МОЗ України від 19.03.2018 р. № 504.

Отримано 10.02.21 